\title{
Antioxidant capacities and total phenolic contents of 20 polyherbal remedies used as tonics by folk healers in Phatthalung and Songkhla provinces, Thailand
}

Wipawee Chanthasri ${ }^{1,2}$, Nuntitporn Puangkeaw ${ }^{2}$, Nongluk Kunworarath ${ }^{2}$, Patcharawalai Jaisamut ${ }^{2}$, Surasak Limsuwan ${ }^{1,2}$, Katesarin Maneenoon ${ }^{2}$, Piyapong Choochana ${ }^{2,3}$ and Sasitorn Chusri ${ }^{1,2^{*}}$ (i)

\begin{abstract}
Background: Uses of polyherbal formulations have played a major role in traditional medicine. The present study is focused on the formulations used in traditional Thai folkloric medicine as tonics or bracers. Twenty documented polyherbal mixtures, used as nourishing tonics by the folk healers in Phatthalung and Songkhla provinces in southern Thailand, are targeted. Despite traditional health claims, there is no scientific evidence to support the utilization of polyherbal formulations.

Methods: The phenolic and flavonoid contents of the polyherbal formulations and a series of antioxidant tests were applied to measure their capability as preventive or chain-breaking antioxidants. In addition, the cytotoxic activity of effective formulations was assayed in Vero cells.

Results: Ninety-eight plant species belonging to 45 families were used to prepare the tested formulation. The preliminary results revealed that water extracts of THP-R016 and THP-R019 contain a high level of total phenolic and flavonoid contents and exhibit remarkable antioxidant activities, as tested by DPPH, ABTS, and FRAP assays. The extract of THP-R019 also showed the strongest metal chelating activities, whereas THP-R016 extract possessed notable superoxide anion and peroxyl radical scavenging abilities.

Conclusions: The data provide evidence that the water extracts of folkloric polyherbal formulations, particularly THP-R016, are a potential source of natural antioxidants, which will be valuable in the pharmaceutical and nutraceutical industries. The free radical scavenging of THP-R016 may be due to the contribution of phenolic and flavonoid contents. Useful characteristics for the consumer, such as the phytochemical profiles of active ingredients, cellular based antioxidant properties and beneficial effects in vivo, are under further investigation.
\end{abstract}

Keywords: Antioxidant activity, Folkloric medicine, Traditional medicine, Tonics

\section{Background}

Traditional medicine, especially herbal therapies, has a crucial role in the health care system in both developing and industrialized countries. According to recent survey results, the percentage taking herbal supplements was almost $20 \%$ in Europe [1]. In several countries, such as

\footnotetext{
* Correspondence: sasitorn.chu@psu.ac.th

${ }^{1}$ Natural Product Research Center of Excellence, Prince of Songkla University, Hat Yai, Songkhla 90110, Thailand

${ }^{2}$ Faculty of Traditional Thai Medicine, Prince of Songkla University, Hat Yai, Songkhla 90110, Thailand

Full list of author information is available at the end of the article
}

Nigeria [2], Turkey [3], Saudi Arabia [4], and Thailand [5], more than $40 \%$ of informants have used herbal medicine. It should be noted that $35 \%$ of respondents in the United States consumed herbal products as antioxidant supplements [6]. Free radicals have emerged as an important cause of oxidative stress-related diseases, including cardiovascular diseases, cancer, neurodegenerative disorders, and ageing. Effective antioxidants can delay or inhibit the oxidation of biomolecules, especially the polyunsaturated fatty acids of cell membranes, or prevent oxidative DNA damage, which affected several 
pathological conditions, including mutagenesis and carcinogenesis [7]. Therefore, herbal medicine may become a useful resource for new antioxidant compounds that can be used for the prevention and treatment of free radical-related diseases.

In recent years, several biological activities related to human health of traditional polyherbal formulations have been reported. The use of herbal-herbal combinations has been found in Ayurvedic [8], Chinese [9] as well as Thai traditional medicine practices [10]. However, the scientific evidence for potential bioactive compounds, therapeutic benefits, and safety information are limited. Recent studies have emphasized the antioxidant properties of polyherbal remedies prescribed in traditional medicine, such as Sahatsatara (Thai traditional medicine) [10], Wuzi Yanzong (Chinese medicine) [3], and Charaka Samhita (Ayurvedic medicine) [4]. Although several surveys on folk medicine in southern Thailand have previously been conducted [11-13], the evaluation of antioxidant activities of polyherbal formulation prescribed by folk healers has never been reported. Therefore, this study is focused on the assessment of antioxidant activities as well as total phenolic and flavonoid contents of 20 documented remedies that were selected based on their traditional uses as tonics or rejuvenators by folk healers in Phatthalung and Songkhla provinces $[14,15]$. A series of antioxidant tests based on single electron transfer (SET) and hydrogen atom transfer (HAT) was used and the effective formulations were additionally tested for their toxicity effects against the Vero cell line.

\section{Methods}

\section{Herbal materials}

Twenty polyherbal remedies with either rejuvenating affects or used as health-promoting tonics were selected from prior studies, as summarized in Table 1. Herbal ingredients of the remedies were locally purchased from a licensed traditional medical drug store, Triburi Orsot in Songkla, Thailand. The plant materials were identified by a botanist, Assistant Professor Dr. Katesarin Maneenoon against reference specimens of the materia medica at the Faculty of Traditional Thai Medicine, Prince of Songkla University, Thailand. The plant parts were washed with sterile distilled water, oven-dried at $60{ }^{\circ} \mathrm{C}$ for $72 \mathrm{~h}$, and then pulverized. The powdered herb was passed through a 16-mesh sieve, weighed, and stored in vacuum-sealed bags at $4{ }^{\circ} \mathrm{C}$ until further use. The mixtures were formulated using different proportions of different types of plant parts, as described in Additional file 1: Table S1.

\section{Preparation of polyherbal extracts}

To prepare the extract, $100 \mathrm{~g}$ of powdered herbal mixture were boiled in $1000 \mathrm{~mL}$ of water at $96.3 \pm 0.6{ }^{\circ} \mathrm{C}$ for
$20 \mathrm{~min}$. The resultant extracts were filtered through a Whatman No. 1 filter paper. The dried extracts were obtained using the freeze-drying process (freeze dryer) and their yields were calculated with respect to the starting materials (Table 3). Each extract was then dissolved in ethanol $(25 \mathrm{mg} / \mathrm{ml})$ for phytochemical and biological analyses. The entire study was performed using one batch of the crude extracts to manipulate batch-to-batch variation and maximize the consistency of the polyherbal extracts.

\section{Quantification of phytochemical contents Total phenolic content (TPC)}

The TPC of each polyherbal extract was quantified based on the Folin-Ciocalteu method according to Abbasi et al. [16] with few modifications. Briefly, $120 \mu \mathrm{L}$ of the extract $(2.5 \mathrm{mg} / \mathrm{mL})$ was mixed with $1 \mathrm{~mL}$ of 10 -fold diluted Folin-Ciocalteu reagent for $5 \mathrm{~min}$, which was followed by the addition of sodium carbonate solution (Ajax Finechem, New Zealand) (1 mL; 20\%w/v). The mixture was then thoroughly mixed and kept in the dark at room temperature for $90 \mathrm{~min}$ before the absorbance was read at $725 \mathrm{~nm}$ (Sunrise ${ }^{\text {Tx }}$ Microplate reader, Tecan Group Ltd., Switzerland). The TPC was expressed as milligrams of gallic acid (Sigma-Aldrich Chemie, Germany) equivalent per gram of extract.

\section{Total flavonoid content (TFC)}

The TFC in the studied samples was estimated by the aluminium chloride colorimetric method as described by Abbasi et al. (2015) [16], with minor modifications. In brief, $50 \mu \mathrm{L}$ of the extract $(2.5 \mathrm{mg} / \mathrm{mL})$ was mixed with $4 \mathrm{~mL}$ of distilled water, $300 \mu \mathrm{L}$ of $5 \%(w / v)$ of sodium nitrite (Ajax Finechem, New Zealand), and $300 \mu \mathrm{L}$ of $10 \%$ $(\mathrm{w} / \mathrm{v})$ aluminium trichloride (Ajax Finechem, New Zealand). The mixture could stand for $6 \mathrm{~min}$ at room temperature; then, $2 \mathrm{~mL}$ of sodium hydroxide $(1 \mathrm{M})$ was added to stop the reaction. The final volume of the mixture was adjusted to $10 \mathrm{~mL}$ with sterile-distilled water and the absorbance was measured at $510 \mathrm{~nm}$ after $10 \mathrm{~min}$ against the reagent blank. The TFC was calculated from a calibration curve using catechin standard solution, and the result was mentioned as milligrams of catechin equivalent per gram of extract.

\section{Gas chromatography-mass spectrometry analysis of essential oils from some herbal ingredients of an effective formula, THP-R016}

Three active herbal ingredients of an effective formula, THP-R016 including Alpinia galanga, Cyperus rotundus, and Piper retrofractum were submitted to hydrodistillation at $100{ }^{\circ} \mathrm{C}$ for $5 \mathrm{~h}$, using a Clevenger-type apparatus. GC-MS analysis of the essential oils were done on a TRACE $^{\text {ma }}$ GC Ultra system (Thermo Scientific, Waltham, 
Table 1 Polyherbal formulas and their medical uses

\begin{tabular}{|c|c|c|}
\hline Remedies & Method of preparation and administration & Traditional uses \\
\hline \multirow[t]{2}{*}{$\overline{\text { THP-RO01 }}$} & Pounded, dried, mixed with honey and made into boluses & \multirow{2}{*}{$\begin{array}{l}\text { refreshing and rejuvenating effect on the entire } \\
\text { body; reduces joint and muscle pain and flatulence }\end{array}$} \\
\hline & Take one bolus twice a day before meals & \\
\hline THP-ROO2 ${ }^{\mathrm{a}}$ & $\begin{array}{l}\text { Pound, mixed with boiled water or honey and made into } \\
\text { boluses; take } 4-5 \text { boluses thrice a day before meals }\end{array}$ & $\begin{array}{l}\text { nourishes the skin; promotes blood circulation and } \\
\text { used as a blood tonic }\end{array}$ \\
\hline THP-R003 & $\begin{array}{l}\text { Pounded, dried, mixed with honey and made into boluses; } \\
\text { take } 2-4 \text { boluses twice a day before meals }\end{array}$ & health tonic and promotes longevity \\
\hline THP-R004 & $\begin{array}{l}\text { Pounded, dried, mixed with honey and made into boluses; } \\
\text { take one bolus once a day before meals }\end{array}$ & $\begin{array}{l}\text { health tonic, skin refreshment, and promotes } \\
\text { longevity }\end{array}$ \\
\hline THP-R005 ${ }^{\mathrm{b}}$ & $\begin{array}{l}\text { Dried and boiled with water; drink } 40-50 \mathrm{~mL} \text { thrice a day } \\
\text { before meals }\end{array}$ & carminative and a tonic \\
\hline THP-R006 ${ }^{\mathrm{b}}$ & $\begin{array}{l}\text { Pounded, dried, mixed with honey and made into boluses; } \\
\text { take two boluses twice a day after meals }\end{array}$ & stimulating and rejuvenating the entire body \\
\hline THP-R007 & $\begin{array}{l}\text { Pounded and infused in hot water }\left(90-97^{\circ} \mathrm{C}, 3-5 \mathrm{~min}\right) \\
\text { drink } 100-150 \mathrm{~mL} \text { of the infusion twice a day after meals }\end{array}$ & health promoting and hypolipidemic agents \\
\hline THP-R008c & $\begin{array}{l}\text { Dried, boiled with water, and filtered the infusion; drink } \\
50-60 \mathrm{~mL} \text { twice a day after meals }\end{array}$ & used as a health tonic and used to treat fatigue \\
\hline THP-R009 & $\begin{array}{l}\text { Dried, boiled with water, and filtered the infusion or pounded, } \\
\text { dried, mixed with honey and made into boluses; drink 50-60 } \\
\mathrm{mL} \text { or take two boluses twice a day after meals }\end{array}$ & $\begin{array}{l}\text { health tonic, sex stimulant, or sexual performance } \\
\text { enhancer }\end{array}$ \\
\hline THP-R010 & $\begin{array}{l}\text { Extracted by boiling water for at least } 3 \mathrm{~h} \text {; drink } 40-50 \mathrm{~mL} \\
\text { thrice a day before meals }\end{array}$ & an appetite inducer and tonic \\
\hline THP-R011 & $\begin{array}{l}\text { Pounded, dried, and made tinctures (alcohol extract) or mixed } \\
\text { with honey and made into boluses; drink } 30 \mathrm{~mL} \text { or take three } \\
\text { boluses once a day before meals }\end{array}$ & $\begin{array}{l}\text { nourishing and tonifying agents; reduces joint and } \\
\text { muscle pain, and applied as a sex stimulant }\end{array}$ \\
\hline THP-R012 & $\begin{array}{l}\text { Dried, boiled with water, and filtered the infusion; drink } \\
40-50 \mathrm{~mL} \text { thrice a day before meals }\end{array}$ & improvement blood circulation tonic \\
\hline THP-R0139 & $\begin{array}{l}\text { Extracted by boiling water for at least } 3 \mathrm{~h} \text {; drink 10-20 mL } \\
\text { thrice a day before meals }\end{array}$ & stimulates and rejuvenates the entire body \\
\hline THP-R014 & $\begin{array}{l}\text { Dried, boiled with water, and filtered the infusion; drink } 5 \mathrm{~mL} \\
\text { thrice a day before meals }\end{array}$ & $\begin{array}{l}\text { health tonic and sex stimulant; reduces joint and } \\
\text { muscle pain and lowers blood glucose }\end{array}$ \\
\hline THP-R015 & $\begin{array}{l}\text { Extracted by boiling water for } 15 \mathrm{~min} \text {; drink } 5 \mathrm{~mL} \text { thrice a day } \\
\text { before meals }\end{array}$ & $\begin{array}{l}\text { tonic, sexual performance enhancer, and lowering } \\
\text { blood glucose }\end{array}$ \\
\hline THP-R016 & $\begin{array}{l}\text { Pounded, dried, and mixed approximately } 5 \mathrm{~g} \text { with } 100 \mathrm{~mL} \text { of } \\
\text { warm water; drink once a day before meals }\end{array}$ & stimulate and rejuvenate the entire body \\
\hline THP-R017' & $\begin{array}{l}\text { Pounded, dried, and mixed approximately } 5 \mathrm{~g} \text { with } 100 \mathrm{~mL} \text { of } \\
\text { warm water; drink once a day before meals }\end{array}$ & blood tonic, reduce joint and muscle pain \\
\hline THP-R018 & $\begin{array}{l}\text { Extracted by boiling water for at least } 3 \mathrm{~h} \text { and filtered the } \\
\text { infusion; drink } 50 \mathrm{~mL} \text { thrice a day before meals }\end{array}$ & stimulate and rejuvenate the entire body \\
\hline THP-R019k & $\begin{array}{l}\text { Pounded, dried, extracted by boiling in water, and filtered } \\
\text { the infusion; drink } 50 \mathrm{~mL} \text { once a day before meals }\end{array}$ & blood tonic; reduce joint and muscle pain \\
\hline THP-R020k & $\begin{array}{l}\text { Pounded, dried, and made tinctures (water extract); drink } \\
50 \mathrm{~mL} \text { once a day before meals }\end{array}$ & health tonic \\
\hline
\end{tabular}

The traditional healers who prescribed the remedies were ${ }^{\mathrm{a}} \mathrm{Mr}$. Prayut Boonyug, ${ }^{\mathrm{b}} \mathrm{Mr}$. But Parnpradit, ${ }^{\mathrm{c}}$ Mr. Yayo Lumkun, ${ }^{\mathrm{d}}$ Mr. Num Nokkeaw, ${ }^{\mathrm{e}} \mathrm{Mr}$. Prasert Kaewpradit, ${ }^{\mathrm{f}} \mathrm{Mr}$. Nhom Ratchgaew, ${ }^{\mathrm{g}} \mathrm{Mr}$. Somporn Chanwanisakul, ${ }^{\mathrm{h}}$ Mr. Yop Lomsa, ${ }^{\mathrm{i}} \mathrm{Mr}$. Lep Boonmee, ${ }^{\mathrm{j}}$ Mr. Kart Eatmong, and ${ }^{\mathrm{k}}$ Mr. Rowan Watjirasoporn

MA) that was attached to an ISQ $^{\text {sm }}$ Series spectrometer. The gas chromatograph was equipped with a TRACE ${ }^{\text {тм }}$ TR-1MS fused-silica capillary column $(30 \mathrm{~m} \times 0.25 \mathrm{~mm}$ id, film thickness $0.25 \mu \mathrm{m}$; Thermo Scientific, San Jose, $\mathrm{CA})$. The $\mathrm{GC}$ oven was held at $60{ }^{\circ} \mathrm{C}$ for $3 \mathrm{~min}$ then ramped to $300{ }^{\circ} \mathrm{C}$ at $5{ }^{\circ} \mathrm{C} / \mathrm{min}$; inlet temperature, $280{ }^{\circ} \mathrm{C}$; carrier gas, $1.0 \mathrm{~mL} / \mathrm{min}$ Helium; injection volume, $1 \mu \mathrm{L}$; split ratio, 10:1. The GC to MS transfer line was maintained at $300{ }^{\circ} \mathrm{C}$ and the mass spectrometer was carried out in electron ionisation mode with an ion source temperature of $250{ }^{\circ} \mathrm{C}$; solvent delay, $3 \mathrm{~min}$. All data were acquired by collecting the full-scan mass spectra within a scanned mass range of 10-400 amu.

\section{Metal-chelating activity (MCA)}

The chelation of ferrous ions by the polyherbal extracts was measured using the methods described by Wong et al., (2014) [17]. Aliquots $(250 \mu \mathrm{L})$ of two-fold dilutions of 
the extract $(0.03-62.50 \mathrm{mg} / \mathrm{mL})$ were mixed with $800 \mu \mathrm{L}$ of distilled water and $25 \mu \mathrm{L}$ of iron (II) chloride $(2 \mathrm{mM})$. The reaction was then initiated by the addition of $50 \mu \mathrm{L}$ of ferrozine $(5 \mathrm{mM})$. After the incubation at room temperature for $10 \mathrm{~min}$, the absorbance of the stable ferrous-ferrozine complex was monitored at $562 \mathrm{~nm}$. The metal chelator, EDTA, was used as a positive control. The percentage chelating capacity was expressed as follows:

$$
\operatorname{MCA}(\%)=\frac{\left(\mathrm{OD}_{\text {control }}-\mathrm{OD}_{\text {sample }}\right) \times 100}{\mathrm{OD}_{\text {control }}}
$$

The MCA values of the extracts and EDTA were expressed as the $50 \%$ inhibition concentration of the ferrous ion ferrozine complex $\left(\mathrm{IC}_{50} ; \mathrm{mg} / \mathrm{mL}\right)$.

\section{Antioxidant properties}

\section{$D P P H$ and ABTS radical scavenging assays}

The radical scavenging ability with DPPH radical was determined according to a previously published method [17]. In brief, a volume of $20 \mu \mathrm{L}$ of each sample at different concentrations (2-fold dilution; 2500-1.22 $\mu \mathrm{g} / \mathrm{mL}$ ) was mixed with $180 \mu \mathrm{L}$ of $80 \mu \mathrm{M}$ DPPH solution in ethanol in a 96-well plate. The plate was shaken and allowed to reach a steady state at room temperature in the dark for $30 \mathrm{~min}$. DPPH bleaching was measured by monitoring the absorbance at $520 \mathrm{~nm}$.

The scavenging activity of the extracts on ABTS radical cation $\left(\mathrm{ABTS}^{+}\right)$was based on the method by Wong et al. [17] with slight modification. Briefly, $\mathrm{ABTS}^{+}$solution was prepared by adding $2 \mathrm{mM}$ ABTS to $2.45 \mathrm{mM}$ potassium persulfate in a volume ratio of 1:1. The mixture was incubated in the dark at room temperature for $16 \mathrm{~h}$, and it was then diluted with ethanol to an absorbance of $0.70 \pm 0.05$ at $734 \mathrm{~nm}$. After the addition of $10 \mu \mathrm{L}$ of each extract at different concentrations (2-fold dilution; $2500-1.22 \mu \mathrm{g} / \mathrm{mL}$ ) to $1 \mathrm{~mL}$ of the diluted ABTS $^{+}$solution, the absorbance at $734 \mathrm{~nm}$ was measured at six minutes after initial mixing.

Appropriate blank measurements were performed and Trolox was used at a positive control. DPPH/ABTS ${ }^{+}$ based-scavenging activities (\%) were calculated using the following equation:

$$
\text { Scavenging activity }(\%)=\frac{\left(\mathrm{OD}_{\text {control }}-\mathrm{OD}_{\text {sample }}\right) \times 100}{\mathrm{OD}_{\text {control }}}
$$

The scavenging ability of the extracts and Trolox were expressed as inhibition concentration $\left(\mathrm{IC}_{50} ; \mathrm{mg} / \mathrm{mL}\right.$ ), causing $50 \%$ inhibition of $\mathrm{DPPH} / \mathrm{ABTS}^{+}$radicals.

\section{Ferric-reducing antioxidant power (FRAP) assay}

The ferric ion reducing power of the extracts was performed according to the procedure described in the literature (Abbasi et al., 2015) [16], which was based on the reduction of ferric-tripyridyl triazine (TPTZ) complex to ferrous-TPTZ that was formed in the presence of electron donating antioxidants at low $\mathrm{pH}$. The FRAP reagent was freshly prepared by mixing $10 \mathrm{~mL}$ of $300 \mathrm{mM}$ acetate buffer, $1 \mathrm{~mL}$ of $10 \mathrm{mM}$ TPTZ solution, and $10 \mathrm{~mL}$ of $20 \mathrm{mM}$ ferric chloride. The tested extracts were diluted in ethanol at a concentration of $0.625 \mathrm{mg} /$ $\mathrm{mL}$. An aliquot of $150 \mu \mathrm{L}$ of the extracts was mixed with $1.35 \mathrm{~mL}$ of the FRAP reagent and then placed at $37{ }^{\circ} \mathrm{C}$ for $30 \mathrm{~min}$ in the dark. The absorption of an intense blue colour complex of ferrous-TPTZ in the reaction mixture was monitored at $596 \mathrm{~nm}$. The calibration curve was obtained by plotting the absorbance at $596 \mathrm{~nm}$ versus ethanol solutions of known ferrous concentrations. The reducing capacity of each extract was expressed as micromoles of ferrous per milligram of extract $(\mu \mathrm{M}$ $\mathrm{Fe}_{2} \mathrm{SO}_{4} / \mathrm{mg}$ extract).

\section{Superoxide anion radical scavenging assay}

The percentage inhibition of superoxide anion generation by eight effective formulations was based on the reduction of nitroblue tetrazolium (NBT). Superoxide radical is generated by the riboflavin/methionine/ illuminate system and assayed by the reduction of NBT to form a purple-coloured formazan $\left(\mathrm{NBT}^{2+}\right)$ caused by the generated superoxide radicals. Briefly, $100 \mu \mathrm{L}$ of NBT $(400 \mu \mathrm{g} / \mathrm{mL})$ was added to $0.4 \mathrm{~mL}$ of the reaction mixture containing riboflavin $(30 \mu \mathrm{g} / \mathrm{mL})$, methionine $(30 \mu \mathrm{g} / \mathrm{mL})$, EDTA $(20 \mu \mathrm{g} / \mathrm{mL})$, and extract (freshly prepared in $0.05 \mathrm{M}$ phosphate buffer, $\mathrm{pH} 7.4$ ) at various concentrations (2-fold dilution; 156.25-4.88 $\mu \mathrm{g} / \mathrm{mL}$ ). The photoinduced reactions were performed by illumination at $25{ }^{\circ} \mathrm{C}$ for $25 \mathrm{~min}$ using fluorescent lamps $(20 \mathrm{~W})$. The absorbance of formazan dye was measured at $560 \mathrm{~nm}$ against an appropriate blank solution. Catechin was used as a positive control. The capability to scavenge superoxide radical was calculated using the equation mentioned above and expressed as the inhibition concentration $\left(\mathrm{IC}_{50} ; \mathrm{mg} / \mathrm{mL}\right)$ causing $50 \%$ inhibition of superoxide anion radicals.

\section{Peroxyl radical scavenging assay}

The assay was modified from the method described by Gillespie et al. [18] in black round bottom 96-well microplates using Trolox as a control standard. Different concentrations of the effective extracts and positive control (2-fold dilution; 100-0.2 $\mu \mathrm{g} / \mathrm{mL}$ ), fluorescein (0.4 nM), and 2,2'-Azobis(2-amidinopropane) dihydrochloride (AAPH) $(153 \mathrm{mM})$ were prepared in $75 \mathrm{mM}$ phosphate buffer ( $\mathrm{pH}$ 7.4). Twenty-five $\mu \mathrm{L}$ of each tested solution was mixed with $150 \mu \mathrm{L}$ of the fluorescein solution and incubated for $30 \mathrm{~min}$ at $37{ }^{\circ} \mathrm{C}$. An aliquot of $25 \mu \mathrm{L}$ of AAPH solution was added, and the decay of 
fluorescence at $528 \mathrm{~nm}$ was immediately monitored with excitation at $485 \mathrm{~nm}$ every $5 \mathrm{~min}$ for $90 \mathrm{~min}$. The antioxidant capacities of the extracts were expressed as $\mu \mathrm{M}$ of Trolox equivalent per $\mu \mathrm{g}$ of the extract ( $\mu \mathrm{M}$ of $\mathrm{TE} / \mu \mathrm{g}$ of $\mathrm{E}$ ).

\section{Cytotoxic effects}

The extracts of effective formulations were further tested for in vitro cytotoxicity on the Vero cell line by green fluorescent protein (GFP)-based assay, which was done by the National Center for Genetic Engineering and Biotechnology, National Science and Technology Development Agency, Pathumthani, Thailand (http://www.biotec.or.th/ bioassay/). Ellipticine was used as a positive control.

\section{Statistical analysis}

Antioxidant activities were analysed in triplicate in at least three different experiments and their results were presented as the mean \pm SD. Statistical analyses of the data were performed using the Statistical Package for the Social Sciences software (SPSS 17) for Windows. The correlation between parameters was performed by Pearson's correlation test and $p$ values less than 0.05 were considered significant. The results were analysed by Student's t-test for comparison between two means. One-way ANOVA with Tukey's HSD as post hoc tests were used to assess differences in multiple samples. A difference was considered statistically significant for $p$ values less than 0.05 .

\section{Results}

\section{Antioxidant related phytochemicals}

Selection of polyherbal formulas to evaluate the antioxidant properties and phenolic contents is based on their traditional use as tonics, rejuvenators, nourishments, or bracers. Thirteen formulas are prescribed by seven folk healers from Songkhla province, and seven formulas are used by four folk healers from Phatthalung province (Fig. 1). As shown in Table 1, decoction and paste were the major modes of preparation; therefore, the hot water extraction method was selected to mimic these traditional medicinal uses of the tested remedies. Extraction yields obtained for the formulation extracts ranged from $2.67-11.83 \%$. The results of this experiment revealed that maximum levels of TPC were found in the water extract of THP-R016 (384.6 $\pm 3.1 \mathrm{mg} \mathrm{GAE} / \mathrm{g}$ extract), which was followed by THP-R019 $(347.4 \pm 12.0 \mathrm{mg}$ GAE/g extract), THP-R010 (269.8 $\pm 11.1 \mathrm{mg} \mathrm{GAE} / \mathrm{g}$ extract), THP-R015 $(211.0 \pm 2.9 \mathrm{mg} \mathrm{GAE} / \mathrm{g}$ extract), and THP-R014 (207.2 $\pm 8.2 \mathrm{mg}$ GAE/g extract), while the minimum value was observed in THP-R001 (39.3 \pm $5.3 \mathrm{mg} \mathrm{GAE} / \mathrm{g}$ extract). The TFC of the studied samples are presented in Table 2, indicating that THP-R019 extract exhibits the highest value $(225.3 \pm 2.4 \mathrm{mg} \mathrm{CAE} / \mathrm{g}$ extract), which was followed by THP-R017 (132.7 \pm $1.5 \mathrm{mg}$ CAE/g extract), THP-R010 (131.2 $\pm 1.5 \mathrm{mg}$ CAE/ g extract), and THP-R014 (103.0 $\pm 3.1 \mathrm{mg} \mathrm{CAE} / \mathrm{g}$ extract), whereas minimum values were noted for THPR020 (34.2 $\pm 1.5 \mathrm{mg} \mathrm{CAE} / \mathrm{g}$ extract).

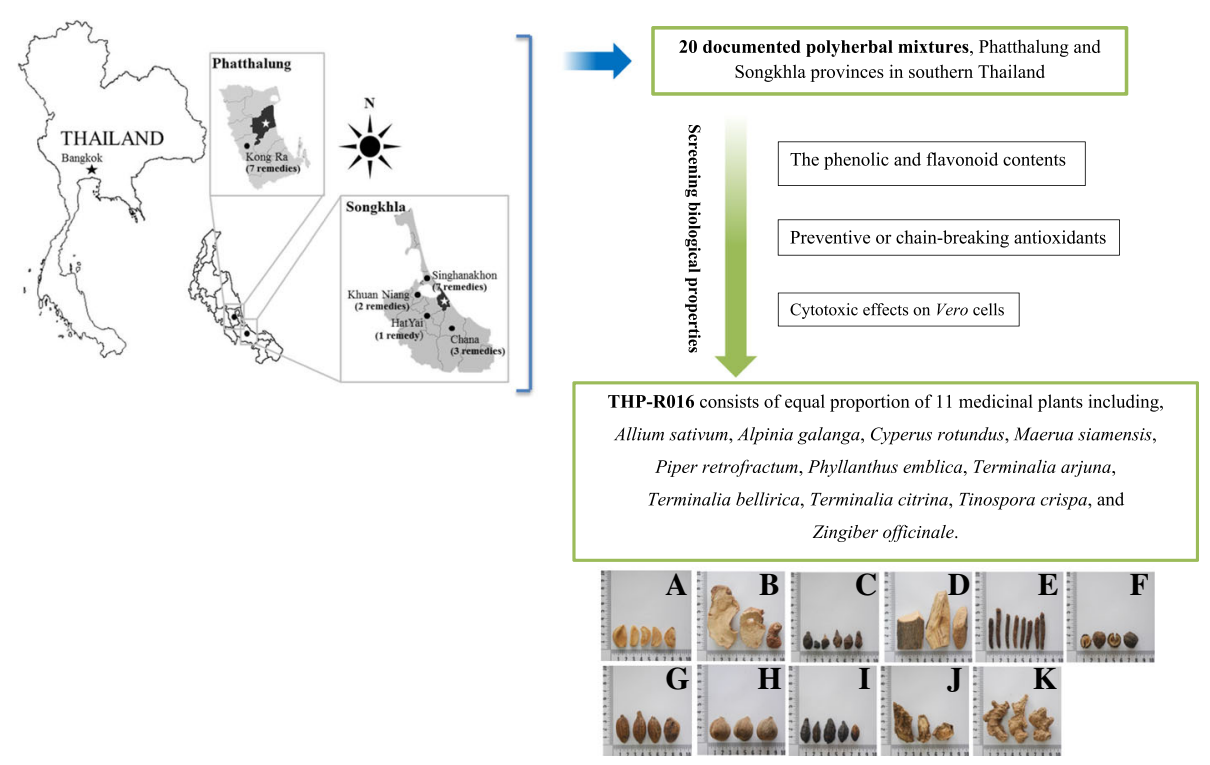

Fig. 1 Map showing the area that herbal remedies used in this study have been found (a blank map of Thailand and regions map of Thailand were taken from http://commons.wikimedia.org with modification),THP-R016 consists of equal proportion of 11 medicinal plants including, Allium sativum L. (a), Alpinia galanga (L.) Willd. (b), Cyperus rotundus L. (c), Maerua siamensis (Kurz) Pax (d), Piper retrofractum Vahl (e), Phyllanthus emblica L. (f), Terminalia arjuna (Roxb. Ex DC.) Wight \& Arn. (g), Terminalia bellirica (Gaertn.) Roxb. (h), Terminalia citrina (Gaertn.) Roxb. ex Fleming (i), Tinospora crispa (L.), Hook. f. \& Thomson (j), and Zingiber officinale Roscoe (k) 
Table 2 Total phenolic and total flavonoid contents of traditional polyherbal formulas

\begin{tabular}{lll}
\hline Samples & $\begin{array}{l}\text { Phenolic content } \\
\text { mg gallic acid/g extract TPC }\end{array}$ & $\begin{array}{l}\text { Flavonoid content } \\
\text { mg catechin/g extract TFC }\end{array}$ \\
\hline THP-R001 & $39.3 \pm 5.3$ & $37.7 \pm 1.8$ \\
THP-R002 & $134.1 \pm 6.3$ & $63.4 \pm 2.3$ \\
THP-R003 & $114.1 \pm 7.1$ & $51.6 \pm 0.9$ \\
THP-R004 & $151.9 \pm 4.6$ & $68.4 \pm 1.0$ \\
THP-R005 & $107.7 \pm 4.8$ & $60.8 \pm 0.2$ \\
THP-R006 & $77.3 \pm 4.6$ & $41.9 \pm 0.1$ \\
THP-R007 & $93.8 \pm 2.7$ & $43.4 \pm 0.1$ \\
THP-R008 & $109.7 \pm 6.8$ & $55.3 \pm 2.3$ \\
THP-R009 & $72.5 \pm 3.1$ & $40.1 \pm 0.3$ \\
THP-R010 & $269.8 \pm 11.1$ & $131.2 \pm 1.5$ \\
THP-R011 & $106.9 \pm 5.1$ & $64.7 \pm 2.0$ \\
THP-R012 & $150.7 \pm 7.5$ & $80.9 \pm 0.8$ \\
THP-R013 & $81.7 \pm 6.1$ & $61.3 \pm 3.1$ \\
THP-R014 & $207.2 \pm 8.2$ & $103.0 \pm 3.1$ \\
THP-R015 & $211.0 \pm 2.9$ & $42.9 \pm 0.9$ \\
THP-R016 & $384.6 \pm 3.1$ & $51.9 \pm 0.7$ \\
THP-R017 & $148.0 \pm 9.5$ & $132.7 \pm 1.5$ \\
THP-R018 & $62.1 \pm 3.4$ & $37.0 \pm 0.2$ \\
THP-R019 & $347.4 \pm 12.0$ & $225.3 \pm 2.4$ \\
THP-R020 & $57.0 \pm 3.4$ & $34.2 \pm 1.5$ \\
\hline
\end{tabular}

\section{Ability of extracts to act as preventive and chain-breaking} antioxidants

THP-R009 exhibited the highest MCA ( $\mathrm{IC}_{50} ; 0.3 \mathrm{mg} /$ $\mathrm{mL}$ ) where THP-R011, THP-R013, THP-R014, THPR017, and THP-R020 were also found to possess the chelating activities $\left(\mathrm{IC}_{50} ; 0.48-0.58 \mathrm{mg} / \mathrm{mL}\right)$, but these activities were lower than that of EDTA. In this study, a negative correlation between phytochemical contents (TPC and TFC) and ferrous ion chelating abilities were observed (Table 4). The antioxidant capacities of the herbal formula extracts was further measured by the reduction of exogenous free radicals using DPPH, ABTS, and FRAP methods. The results of ferric reducing capacities of the extracts are given in Table 3. Among all tested extracts, THP-R019 had the highest FRAP value (96.86 $\pm 1.63 \mu \mathrm{M} \quad \mathrm{Fe}_{2} \mathrm{SO}_{4} / \mathrm{mg}$ extract), which was followed by THP-R016 (95.76 $\pm 2.35 \mu \mathrm{M} \mathrm{Fe} \mathrm{SO}_{4} / \mathrm{mg}$ extract), THP-R012 (87.12 $\pm 1.15 \mu \mathrm{M} \mathrm{Fe} \mathrm{SO}_{4} / \mathrm{mg}$ extract), and THP-R015 (84.22 $\pm 1.23 \mu \mathrm{M} \mathrm{Fe} \mathrm{SO}_{4} / \mathrm{mg}$ extract), respectively. The radical scavenging effects of the sample extracts were primarily assessed using the DPPH and ABTS assays. The trend for these radical scavenging activities of the 20 tested extracts did not vary markedly from their ferric reducing capacities. Similar to the results obtained from FRAP assays, THP-R016 and THP-
R019 extracts showed very strong scavenging activities against both $\mathrm{DPPH}$ and ABTS radicals. The $\mathrm{IC}_{50}$ value of THP-R016 extract in the ABTS assay was $0.34 \mathrm{mg} /$ $\mathrm{mL}$, which was comparable to the value of Trolox. The $\mathrm{IC}_{50}$ value of this extract on DPPH radicals was 2 times more than that of the standard.

\section{Correlation between free radical inhibition activity and phenolic compounds}

The Pearson's correlation coefficients were evaluated to describe the inter-relationships of the results obtained with the different methods in the polyherbal formulation extracts (Table 4). There were significantly high positive correlations between antioxidant properties and TPC. In addition, the results revealed that there were moderate positive correlations between TFC and the antioxidant properties.

\section{Inhibitory activity of extracts on superoxide anion radicals and cytotoxic effects}

As presented in Fig. 2a, the tested extracts scavenged superoxide anion in the riboflavin/methionine/illuminate system in a concentration-dependent manner. The $\mathrm{IC}_{50}$ values of THP-R004, THP-R009, THP-R010, THP-R012, THP-R014, THP-R015, THP-R016, and THP-R019 for scavenging the free radicals were found to be $184.7 \pm$ $10.4, \quad 486.6 \pm 18.9, \quad 73.6 \pm 1.0, \quad 215.3 \pm 5.6, \quad 189.0 \pm 4.9$, $133.8 \pm 2.7,70.0 \pm 1.2$, and $107.7 \pm 1.0 \mu \mathrm{g} / \mathrm{mL}$, respectively. The $\mathrm{IC}_{50}$ values of THP-R010 and THP-R016 were significantly less than that of the other extracts, which clearly indicated their greater efficiency as superoxide anion scavengers (Fig. 2b). Moreover, the non-cytotoxic effect was observed in normal cell lines when the cells were incubated for $24 \mathrm{~h}$ with THP-R004, THP-R015, and THP-R016. These effective formulas have an $\mathrm{IC}_{50}$ greater than $50 \mu \mathrm{g} / \mathrm{mL}$ against Vero cells, these values were found to be higher than a positive control, ellipticine $\left(\mathrm{IC}_{50}\right.$ value of $0.68 \mu \mathrm{g} / \mathrm{mL}$ ).

\section{Peroxyl radical scavenging activity of an effective remedy, THP-R016}

The present study shows that the fluorescence signal of fluorescein in the assay solutions of THP-R016 at concentration ranging from 3.1 to $100.0 \mu \mathrm{g} / \mathrm{mL}$ and trolox at $100 \mu \mathrm{M}$ was stable for $90 \mathrm{~min}$ (Fig. 3). In this study, THP-R016 exhibits peroxyl radical scavenging properties with an ORAC value of $705.48 \pm$ 33.44 $\mu \mathrm{M}$ Trolox/ $\mu \mathrm{g}$ of extract. The GC-MS analysis (Table 5) revealed the major constituents as caryophyllen, pentadecane, 1,4,7,-cycloundecatriene, 1,5,9,9tetramethyl-, Z,Z,Z-, 8-heptadecene, and heptadecane for the essential oil extracted from Piper retrofractum; 4-isopropyl-1-methoxy-1,6-dimethyl-1,2,3,4-tetrahydronaphthalene, copaene, $\alpha$-cubebene, $\beta$-calacorene, and 
Table 3 Extraction yields and antioxidant capacities of polyherbal formulas

\begin{tabular}{|c|c|c|c|c|c|}
\hline \multirow[t]{2}{*}{ Samples } & \multirow{2}{*}{$\begin{array}{l}\text { Yields } \\
\%(w / w)\end{array}$} & \multirow{2}{*}{$\begin{array}{l}\mathrm{MCA}^{\mathrm{a}} \\
\mathrm{I} \mathrm{C}_{50}(\mathrm{mg} / \mathrm{mL})\end{array}$} & \multirow{2}{*}{$\begin{array}{l}\text { FRAP }^{\mathrm{b}} \text { assay } \\
\mu \mathrm{M} \mathrm{Fe} \mathrm{SO}_{4} / \mathrm{mg} \text { extract }\end{array}$} & \multicolumn{2}{|c|}{ Radical scavenging activities; $1 \mathrm{C}_{50}(\mathrm{mg} / \mathrm{mL})$} \\
\hline & & & & $\mathrm{DPPH}$ & ABTS \\
\hline THP-R001 & 5.68 & $0.93 \pm 0.00$ & $11.61 \pm 0.25$ & - & - \\
\hline THP-R002 & 4.60 & $0.94 \pm 0.01$ & $39.79 \pm 0.72$ & $2.15 \pm 0.41$ & $1.15 \pm 0.00$ \\
\hline THP-R003 & 5.68 & $0.63 \pm 0.02$ & $18.58 \pm 0.35$ & - & $2.01 \pm 0.03$ \\
\hline THP-R004 & 3.99 & $0.80 \pm 0.01$ & $42.51 \pm 0.76$ & $0.92 \pm 0.02$ & $1.09 \pm 0.06$ \\
\hline THP-R005 & 10.54 & $0.84 \pm 0.01$ & $38.84 \pm 0.78$ & $1.61 \pm 0.03$ & $1.38 \pm 0.04$ \\
\hline THP-R006 & 8.93 & $0.64 \pm 0.01$ & $15.63 \pm 0.30$ & - & $1.96 \pm 0.10$ \\
\hline THP-R007 & 8.07 & $0.64 \pm 0.01$ & $20.86 \pm 0.65$ & - & $1.45 \pm 0.05$ \\
\hline THP-R008 & 10.95 & $0.88 \pm 0.01$ & $51.62 \pm 0.46$ & $1.77 \pm 0.05$ & $1.31 \pm 0.03$ \\
\hline THP-R009 & 11.83 & $0.30 \pm 0.01$ & $20.27 \pm 0.46$ & $2.42 \pm 0.05$ & $1.79 \pm 0.02$ \\
\hline THP-R010 & 8.26 & $2.81 \pm 0.04$ & $87.12 \pm 1.15$ & $0.53 \pm 0.02$ & $0.42 \pm 0.00$ \\
\hline THP-R011 & 8.52 & $0.58 \pm 0.02$ & $30.33 \pm 0.65$ & $2.10 \pm 0.03$ & $1.31 \pm 0.01$ \\
\hline THP-R012 & 9.04 & $1.46 \pm 0.06$ & $40.70 \pm 0.95$ & $1.04 \pm 0.07$ & $0.87 \pm 0.01$ \\
\hline THP-R013 & 10.07 & $0.49 \pm 0.01$ & $20.92 \pm 0.27$ & $2.22 \pm 0.04$ & $1.89 \pm 0.05$ \\
\hline THP-R014 & 2.67 & $0.58 \pm 0.02$ & $54.55 \pm 1.24$ & $1.43 \pm 0.07$ & $0.55 \pm 0.01$ \\
\hline THP-R015 & 5.52 & $1.21 \pm 0.01$ & $84.22 \pm 1.23$ & $0.43 \pm 0.02$ & $0.70 \pm 0.01$ \\
\hline THP-R016 & 10.96 & $1.27 \pm 0.02$ & $95.76 \pm 2.35$ & $0.16 \pm 0.00$ & $0.34 \pm 0.00$ \\
\hline THP-R017 & 4.60 & $0.58 \pm 0.02$ & $82.32 \pm 0.81$ & $1.51 \pm 0.24$ & $1.07 \pm 0.01$ \\
\hline THP-R018 & 3.13 & $0.95 \pm 0.02$ & $18.75 \pm 0.42$ & - & $2.46 \pm 0.10$ \\
\hline THP-R019 & 4.31 & $1.24 \pm 0.03$ & $96.86 \pm 1.63$ & $0.50 \pm 0.02$ & $0.40 \pm 0.01$ \\
\hline THP-R020 & 4.09 & $0.57 \pm 0.01$ & $18.57 \pm 0.15$ & - & - \\
\hline Trolox & - & - & - & $0.09 \pm 0.01$ & $0.34 \pm 0.01$ \\
\hline EDTA $(\mu \mathrm{g} / \mathrm{mL})$ & - & $8.48 \pm 0.34$ & - & - & - \\
\hline
\end{tabular}

; Not applicable

${ }^{a}$ MCA; metal chelating activity

${ }^{\mathrm{b}} \mathrm{FRAP}$; ferric ion reducing antioxidant power

11-hydroxy-2,3,4,11-tetrahydro-6H-pyrimido[2,1-b]quinazolin-6-one for Cyperus rotundus; and $\beta$-bisabolene, cis- $\alpha$-bergamotene, $\beta$-sesquiphellandrene, 1,8-cineole, and chavicol, acetate for Alpinia galangal.

\section{Discussion}

Secondary metabolites of plants in particular phenolics and flavonoids are generally involved in defence against oxidative stress-related degenerative disorders. In addition, several reports have shown a correlation between the consumption of plant-derived antioxidants and numerous health benefits in humans $[19,20]$. Polyphenolic compounds are the most abundant groups of plant metabolites that structurally possess an aromatic benzene ring with one or more hydroxyl constituents. The antioxidant activity of phenolic compounds is

Table 4 The correlation analysis of total antioxidant capacities and main active ingredients of water extracts prepared from 20 polyherbal medicines used as rejuvenators

\begin{tabular}{|c|c|c|c|c|c|}
\hline & \multicolumn{5}{|c|}{ Pearson's correlation ( $p$ value) } \\
\hline & $\overline{\mathrm{ABTS}^{\mathrm{a}}}$ & FRAP $^{a}$ & $M_{C A}^{a}$ & $T P C^{b}$ & $\mathrm{TFC}^{\mathrm{b}}$ \\
\hline$\overline{\mathrm{DPPH}^{\mathrm{a}}}$ & $0.959(0.000)$ & $0.884(0.000)$ & $-0.690(0.001)$ & $0.882(0.000)$ & $0.592(0.006)$ \\
\hline ABTS & & $0.897(0.000)$ & $-0.711(0.000)$ & $0.939(0.000)$ & $0.695(0.001)$ \\
\hline FRAP & & & $-0.734(0.000)$ & $0.895(0.000)$ & $0.699(0.001)$ \\
\hline MCA & & & & $-0.751(0.000)$ & $-0.449(0.047)$ \\
\hline TPC & & & & & $0.682(0.001)$ \\
\hline
\end{tabular}

${ }^{a}$ Antioxidant capacities of the extracts were expressed in terms of their inhibitory activity against ABTS• + and DPPH radicals (\% inhibition at $1.2 \mathrm{mg} / \mathrm{mL}$ ), ferric reducing antioxidant power (FRAP; $\mu \mathrm{M} \mathrm{Fe}_{2} \mathrm{SO}_{4} / \mathrm{mg}$ extract), and ferrous ions metal chelating activity (MCA; \% chelating activity at $3.5 \mathrm{mg} / \mathrm{mL}$ ) ${ }^{\mathrm{b}}$ Total phenolic content (TPC) and total flavonoid content (TFC) expressed as mg of gallic acid equivalent per $\mathrm{g}$ extract and mg catechin equivalent per $\mathrm{g}$ extract, respectively 


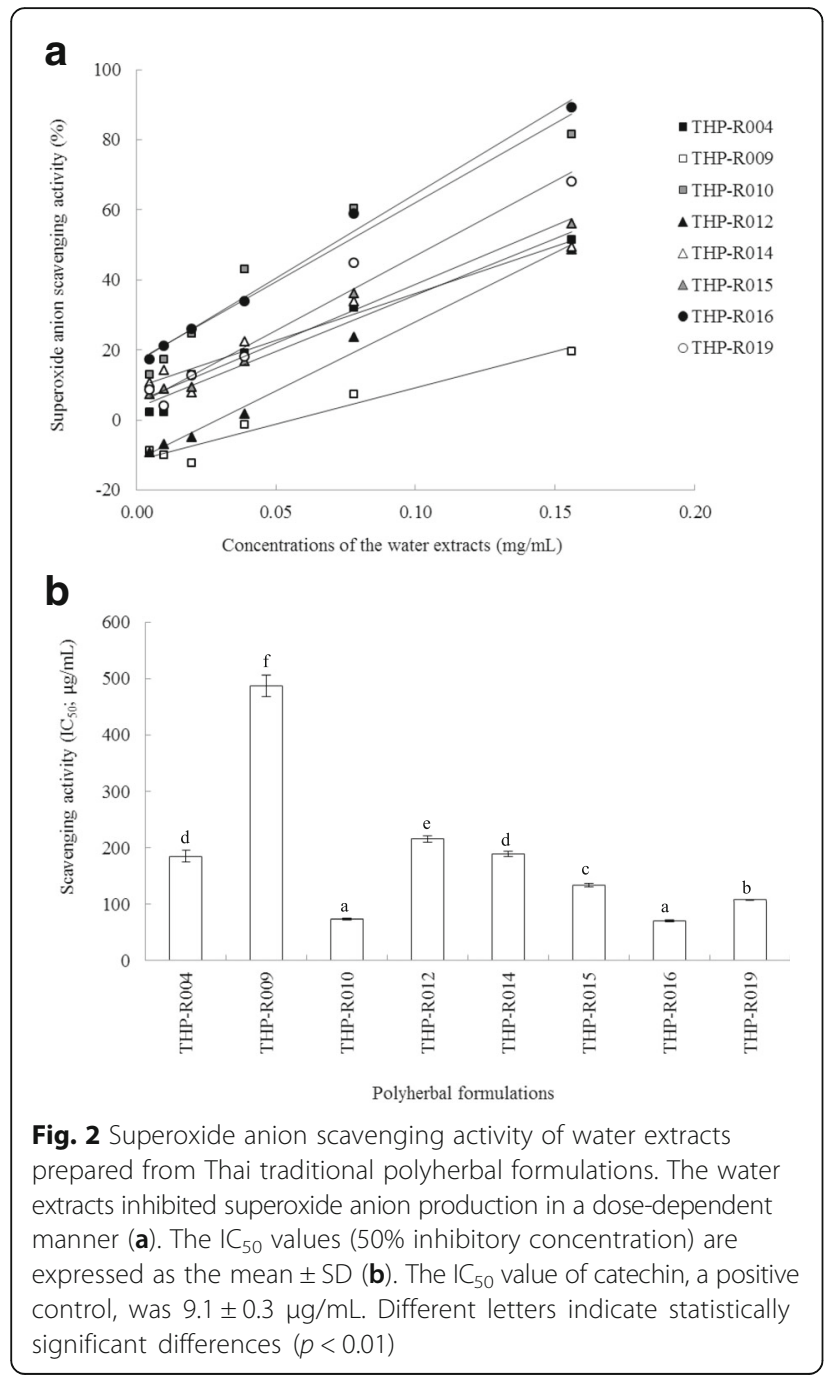

mainly due to their ability to act as reducing agents, hydrogen donors, singlet and triplet oxygen quenchers, and metal chelators $[16,20]$. Flavonoids, the major class of polyphenolic compounds, have a common basic structure that consists of two aromatic rings linked with a heterocyclic pyrane ring. The compounds are known to have antioxidant activity by acting as effective scavengers of various free radicals as well as singlet oxygen [20]. The high phenolic and flavonoid contents found in some remedies, such as THP-R010, THPR014, THP-R015, THP-R016, THP-R017, and THP-R019, may indicate their antioxidant activities and support their acclaim as bracers.

To confirm the beneficial effects on antioxidant abilities, the water extracts of the traditional remedies were primarily assessed for their ability to be either preventive antioxidants, demonstrated by MCA or chain-breaking antioxidants, which were tested using both the single electron transfer mechanism (SET)-based assay (FRAP) and mixed-mode-based assays (DPPH and ABTS

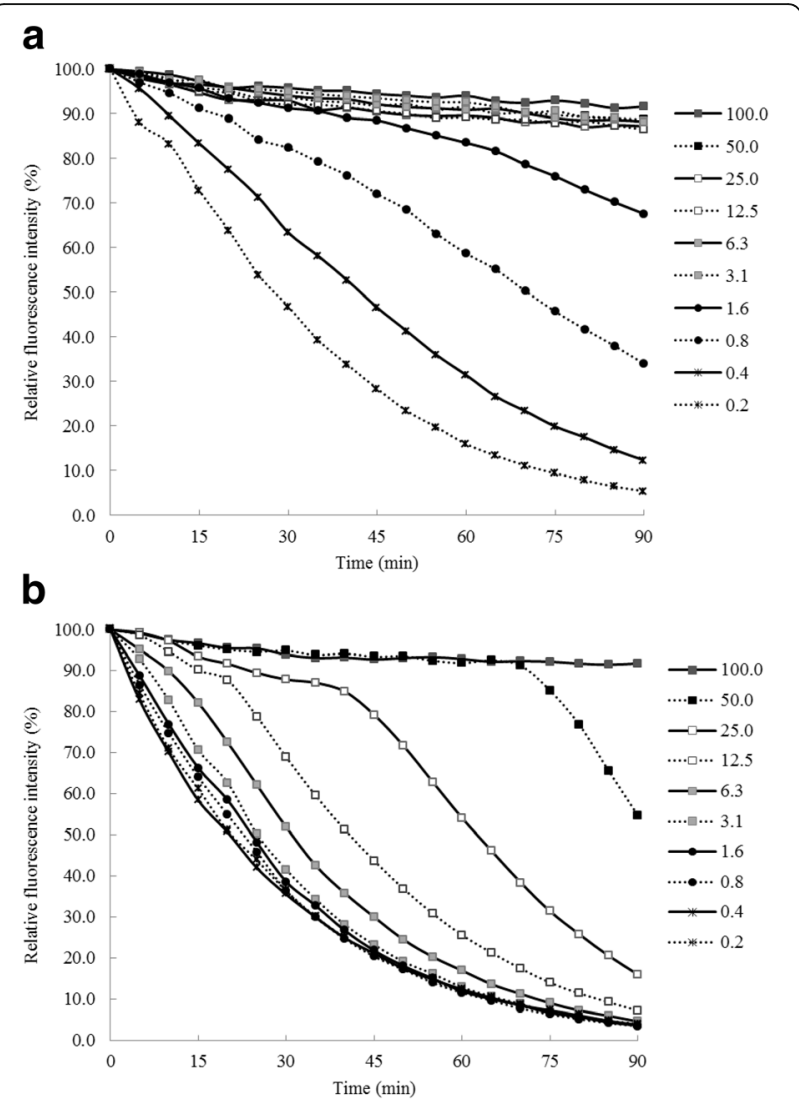

Fig. 3 Anti-peroxyl radical activity, fluorescence decay curves of fluorescein in the presence of THP-R016 water extract (a) and the reference antioxidant trolox (b)

scavenging activities) [21, 22]. Metal-mediated formation of hydroxyl radical by the well-known redox cycling process, Fenton reaction, may lead to protein oxidation, DNA damage, and lipid peroxidation [23]. Among the transition metals, ferrous ion is well-recognized as a potential catalysing agent. Hence, ferrous ion chelators may offer protective effects for oxidative damage. This result suggested that the chelating properties of the extracts could be due to the presence of compounds other than phenolics and flavonoids. Previous studies showed that polysaccharides from some medicinal plants [24] possess their abilities to chelate metal ion. It must be noted that the water extract prepared from THP-R014 with relatively high phenolic and flavonoid contents also showed good chelation of ferrous ion. It has been reported that plant-derived compounds, including phenolic acids, flavonoid quercetin, and phenolic glycosides with functional groups of hydroxyl, sulfhydryl, carbonyl, and phosphate, show chelating activity on transition metal ions, including ferrous ion [25].

According to these findings, it should also be noted that phenolic compounds in the herbal remedies are the major contributor to antioxidant capacities. However, 
Table 5 Phyto-constituents identified in three essential oils of Piper retrofractum Vahl., Alpinia galanga L., and Cyperus rotundus L

\begin{tabular}{|c|c|c|c|c|c|c|c|}
\hline Medicinal plants & Yield & RT & Compound names & Match Factor & Formula & $\mathrm{MW}$ & \%Peak area \\
\hline \multirow[t]{5}{*}{ Alpinia galanga $\mathrm{L}$. } & \multirow[t]{5}{*}{0.43} & 20.72 & $\beta$-Bisabolene & 95.7 & $\mathrm{C}_{15} \mathrm{H}_{24}$ & 204 & 14.0 \\
\hline & & 18.91 & cis-a-Bergamotene & 96.6 & $\mathrm{C}_{15} \mathrm{H}_{24}$ & 204 & 10.0 \\
\hline & & 21.06 & $\beta$-Sesquiphellandrene & 94.0 & $\mathrm{C}_{15} \mathrm{H}_{24}$ & 204 & 9.7 \\
\hline & & 8.08 & 1,8-Cineole & 97.3 & $\mathrm{C}_{10} \mathrm{H}_{18} \mathrm{O}$ & 154 & 6.0 \\
\hline & & 16.55 & Chavicol, acetate & 98.8 & $\mathrm{C}_{11} \mathrm{H}_{12} \mathrm{O}_{2}$ & 176 & 4.3 \\
\hline \multirow[t]{5}{*}{ Cyperus rotundus L. } & \multirow[t]{5}{*}{1.02} & 21.31 & $\begin{array}{l}\text { 4-Isopropyl-1-methoxy-1,6-dimethyl- } \\
\text {-1,2,3,4-tetrahydronaphthalene }\end{array}$ & 90.3 & $\mathrm{C}_{15} \mathrm{H}_{22}$ & 202 & 11.7 \\
\hline & & 17.52 & Copaene & 95.2 & $\mathrm{C}_{15} \mathrm{H}_{24}$ & 204 & 5.0 \\
\hline & & 16.81 & a-Cubebene & 94.5 & $\mathrm{C}_{15} \mathrm{H}_{24}$ & 204 & 4.7 \\
\hline & & 21.69 & $\beta$-Calacorene & 89.9 & $\mathrm{C}_{15} \mathrm{H}_{20}$ & 200 & 4.5 \\
\hline & & 21.61 & $\begin{array}{l}\text { 11-hydroxy-2,3,4,11-tetrahydro-6H-pyrimido } \\
\text { [2,1-b]quinazolin-6-one }\end{array}$ & 71.5 & $\mathrm{C}_{11} \mathrm{H}_{11} \mathrm{~N}_{3} \mathrm{O}_{2}$ & 217 & 3.9 \\
\hline \multirow[t]{5}{*}{ Piper retrofractum Vahl. } & \multirow[t]{5}{*}{0.87} & 18.59 & Caryophyllene & 92.1 & $\mathrm{C}_{15} \mathrm{H}_{24}$ & 204 & 9.4 \\
\hline & & 20.52 & Pentadecane & 96.7 & $\mathrm{C}_{15} \mathrm{H}_{32}$ & 212 & 7.4 \\
\hline & & 19.42 & $\begin{array}{l}\text { 1,4,7,-Cycloundecatriene, 1,5,9,9-tetramethyl-, } \\
\text { Z,Z,Z- }\end{array}$ & 95.0 & $\mathrm{C}_{15} \mathrm{H}_{24}$ & 204 & 6.8 \\
\hline & & 24.78 & 8-Heptadecene & 96.0 & $\mathrm{C}_{17} \mathrm{H}_{34}$ & 238 & 6.8 \\
\hline & & 25.06 & Heptadecane & 96.6 & $\mathrm{C}_{17} \mathrm{H}_{36}$ & 240 & 6.1 \\
\hline
\end{tabular}

this is apparently because of both flavonoid and nonflavonoid phenolics. This result is also similar to the previous studies that found a stronger correlation between the total phenolic content and ABTS assay than the DPPH assay $[26,27]$. Both ABTS and DPPH assays were considered mixed-mode methods, and their radicals can be neutralized by SET and HAT mechanisms [21]. ABTS radical cation is applicable to both hydrophilic and lipophilic systems [28], while the radical produced in the DPPH assay is appropriate for hydrophobic systems [29]. Moreover, it has been reported that the difference between antioxidant capacities evaluated by the two methods may be affected by the pigment in the tested extracts [28]. There was a strong association between the antioxidant capacities measured by the ABTS/DPPH assays and FRAP method, which is based on the SET mechanism. This may be explained by the observation that a redox potential of the ferrous/ferric couple is comparable to that of $\mathrm{ABTS} / \mathrm{ABTS}^{+\bullet}$ redox coupling with values approximately quoted as approximately $0.77 \mathrm{~V}$ and $0.68 \mathrm{~V}$, respectively [30]. Therefore, as expected, extracts obtained from polyherbal remedies had similar antioxidant capacities detected by ABTS/DPPH and FRAP assays, which should lead to a significant correlation between the results.

Based on the initial screening, eight effective formulation extracts were selected and tested for their superoxide scavenging activities. Superoxide anion radicals $\left(\mathrm{O}_{2}^{\circ-}\right)$ are mainly generated by activated phagocytes and the mitochondrial electron-transport chain of aerobic respiration, although $\mathrm{O}_{2}^{*-}$ is not very reactive damaging agents for DNA and polyunsaturated fatty acids in lipids. The physiological radicals play an important role as a precursor of more reactive species, especially hydroxyl radicals that initiate lipid peroxidation and induce several pathophysiological processes [31]. The measurement of the antioxidant capacity of the effective remedy, THPR016, was further confirmed using the HAT-based assay. The ability of THP-R016 water extract to capture endogenous radicals, such as peroxyl radicals that mediated the oxidation of biological targets, was tested using the ORAC assay. Although, the reaction mechanism of the test is more complex than that of the mixed-modeand SET-based methods, it has the advantage of acting on physiological radicals [22].

According to the literature, this Thai traditional rejuvenating formulation, THP-R016, is a preparation consisting of 11 medicinal plants, which are Allium sativum, Alpinia galanga, Cyperus rotundus, Maerua siamensis, Piper retrofractum, Phyllanthus emblica, Terminalia arjuna, Terminalia bellirica, Terminalia citrina, Tinospora crispa, and Zingiber officinale. Except for M. siamensis, all medicinal plants have been recorded to possess notable antioxidant capacity. Previous studies demonstrated that piperoside isolated from $P$. retrofractum exhibited moderate peroxyl radical scavenging and reducing potential activity [32], while Terminalia citrina was found to display protective effects against oxidant-induced Heinz body formation [33], which contributes to anaemia. Reported active constituents, including total oligomeric flavonoid fractions, nootkatone, aristolone, solavetivone, and orientin obtained from Cyperus 
rotundus, have protective effects against lipid peroxidation, DNA damage, antihemolytic activity, and anticancer treatment for erythroleukaemia cells, which might be correlated with their high antioxidant activities [34]. Earlier experiments have also demonstrated that Alpinia galangal exerts in vitro antimelanogenesis activity [35] and in vivo antiamnesiac activity through its antioxidant properties [36]. In addition to their well-described in vitro antioxidant activities, several in vivo studies demonstrated that consumption of Allium sativum [37], Zingiber officinale [38], Terminalia arjuna [39], and Tinospora crispa [40] extracts led to significant increases in antioxidant enzymes, such as superoxide dismutase, glutathione peroxidase, and catalase, and suppressed glutathione depletion and lipid peroxidation. It should be noted that the herbal components of THP-R016, Terminalia bellirica and Phyllanthus emblica, are components of Ayurvedic polyherbal formulas Charaka Samhita [8] and Triphala [41], which were used as antihyperglycemic and rejuvenation agents, respectively.

\section{Conclusions}

From the present study, our findings provide evidence that the water extracts of folkloric polyherbal formulations, especially THP-R016, are a potential source of natural antioxidants, justifying their uses as a health tonic in folk medicines. The extracts exhibited notable free radical scavenging that may be due to the contribution of phenolic and flavonoid contents. However, further investigations need to be performed to measure the antioxidant compounds or determine the in vivo biological activities of these extracts, which are being investigated by our group. This information would be helpful for applying THP-R016 as a traditional-based antioxidant in therapeutic drugs for the implications of human health.

\section{Additional file}

Additional file 1: Table S1. Ingredients and proportions of Thai traditional polyherbal formulation used as rejuvenators. (DOCX $55 \mathrm{~kb}$ )

\section{Abbreviations}

ABTS: 2,2'-azino-bis (3-ethylbenzothiazoline-6-sulfonic acid); DPPH: 2,2diphenyl-1-picrylhydrazyl; MCA: Metal-chelating activity; MTT: Methyl thiazol tetrazolium; TFC: Total flavonoid content; THP: Traditional herbal preparation; TPC: Total phenolic content; TPTZ: Tripyridyl triazine

\section{Acknowledgements}

The authors are very grateful to Natural Product Research Center of Excellence, Prince of Songkla University for the postgraduate fellowship.

\section{Funding}

This work was supported by Grants for a General Researcher, Halal Institute, Prince of Songkla University [TM06H58; 2014-2015] and partly supported by TRF Senior Research Scholar, the Thailand Research Fund [Grant No. RTA5880005]. Miss Wipawee Chanthasri was funded by Natural Product Research Center of Excellence Postgraduate Scholarship.

\section{Availability of data and materials}

All data generated or analysed during this study are included in this published article. A supplementary file named "Additional file 1: Table S1" is described ingredients and proportions of 20 Thai traditional polyherbal formulations used as rejuvenators. The formulations were prepared according to the mentioned proportion and extracted with water as described in 'Method' section.

\section{Authors' contributions}

WC and SC designed, carried out the experiments, and wrote the manuscript; $\mathrm{NP}$ and KM contributed to plant collection and identification; NK, PJ and SL critically revised the manuscript. PC carried out the GC-MS experiment. All authors read the manuscript and approved the final version.

\section{Ethics approval and consent to participate}

Not applicable

\section{Consent for publication}

Not applicable

\section{Competing interests}

The authors declare that they have no competing interests.

\section{Publisher's Note}

Springer Nature remains neutral with regard to jurisdictional claims in published maps and institutional affiliations.

\section{Author details}

${ }^{1}$ Natural Product Research Center of Excellence, Prince of Songkla University, Hat Yai, Songkhla 90110, Thailand. ${ }^{2}$ Faculty of Traditional Thai Medicine, Prince of Songkla University, Hat Yai, Songkhla 90110, Thailand. ${ }^{3}$ Faculty of Oriental Medicine, Rangsit University, Pathumthani, Thailand.

Received: 12 April 2017 Accepted: 8 February 2018

Published online: 21 February 2018

\section{References}

1. Garcia-Alvarez A, Egan B, de Klein S, Dima L, Maggi FM, Isoniemi M, RibasBarba L, Raats MM, Meissner EM, Badea M, et al. Usage of plant food supplements across six European countries: findings from the PlantLIBRA consumer survey. PLoS One. 2014;9(3):e92265.

2. Onyeka TC, Ezike HA, Nwoke OM, Onyia EA, Onuorah EC, Anya SU, Nnacheta TE. Herbal medicine: a survey of use in Nigerian presurgical patients booked for ambulatory anaesthesia. BMC Complement Altern Med. 2012;12(1):130.

3. Soner BC, Sahin AS, Sahin TK. A survey of Turkish hospital patients' use of herbal medicine. Eur J Integr Med. 2013;5(6):547-52.

4. Mohammad Y, Al-Ahmari A, Al-Dashash F, Al-Hussain F, Al-Masnour F, Masoud A, Jradi H. Pattern of traditional medicine use by adult Saudi patients with neurological disorders. BMC Complement Altern Med. 2015;15:102.

5. Tangkiatkumjai M, Boardman H, Praditpornsilpa K, Walker DM. Prevalence of herbal and dietary supplement usage in Thai outpatients with chronic kidney disease: a cross-sectional survey. BMC Complement Altern Med. 2013:13:153.

6. Sweet E, Dowd F, Zhou M, Standish L, Andersen MR. The use of complementary and alternative medicine supplements of potential concern during breast cancer chemotherapy. Evid Based Complement Alternat Med. 2016;2016:8.

7. Willcox JK, Ash SL, Catignani GL. Antioxidants and prevention of chronic disease. Crit Rev Food Sci Nutr. 2004;44(4):275-95.

8. Kuchewar W, Borkar MA, Nisargandha MA. Evaluation of antioxidant potential of Rasayana drugs in healthy human volunteers. Ayu. 2014;35(1):46-9.

9. Ji HJ, Wang DM, Wu YP, Niu YY, Jia LL, Liu BW, Feng QJ, Feng ML. Wuzi Yanzong pill, a Chinese polyherbal formula, alleviates testicular damage in mice induced by ionizing radiation. BMC Complement Altern Med. 2016;16(1):509.

10. Booranasubkajorn $S$, Huabprasert $S$, Wattanarangsan J, Chotitham $P$, Jutasompakorn P, Laohapand T, Akarasereenont P, Tripatara P. Vasculoprotective and vasodilatation effects of herbal formula (Sahatsatara) and piperine in spontaneously hypertensive rats. Phytomedicine. 2017;24:148-56.

11. Neamsuvan O, Bunmee P. A survey of herbal weeds for treating skin disorders from southern Thailand: Songkhla and Krabi Province. J Ethnopharmacol. 2016;193:574-85. 
12. Neamsuvan O, Madeebing N, Mah L, Lateh W. A survey of medicinal plants for diabetes treating from Chana and Nathawee district, Songkhla province. Thailand J Ethnopharmacol. 2015;174:82-90.

13. Maneenoon K, Khuniad C, Teanuan Y, Saedan N, Prom-In S, Rukleng N, Kongpool W, Pinsook P, Wongwiwat W. Ethnomedicinal plants used by traditional healers in Phatthalung Province, peninsular Thailand. J Ethnobiol Ethnomed. 2015;11:43

14. Maneenoon K, Wongwiwat W, Pinsook S. Utilization knowledge in medicinal plants of traditional healers in Phatthalung province: PSU Knowledge Bank; 2010. http://kb.psu.ac.th/psukb/handle/2010/9897. Accessed 23 Aug 2014.

15. Subhadhirasakul S, Sakulkeo O, Chamnan W, Kanchanampa D, Maneenoon K, Viriyahbupha C. Utilization knowledge in medicinal plants of traditional healers in Songkhla and Satun provinces: PSU Knowledge Bank; 2010. http://kb.psu.ac.th/psukb/handle/2553/4209. Accessed 23 Aug 2014.

16. Abbasi AM, Shah MH, Li T, Fu X, Guo X, Liu RH. Ethnomedicinal values, phenolic contents and antioxidant properties of wild culinary vegetables. J Ethnopharmacol. 2015;162:333-45.

17. Wong FC, Yong AL, Ting EP, Khoo SC, Ong HC, Chai TT. Antioxidant, metal chelating, anti-glucosidase activities and phytochemical analysis of selected tropical medicinal plants. Iran J Pharm Res. 2014;13(4):1409-15.

18. Gillespie KM, Chae JM, Ainsworth EA. Rapid measurement of total antioxidant capacity in plants. Nat Protoc. 2007;2(4):867-70.

19. Yao LH, Jiang YM, Shi J, Tomas-Barberan FA, Datta N, Singanusong R, Chen SS. Flavonoids in food and their health benefits. Plant Foods Hum Nutr. 2004;59(3):113-22.

20. Pandey KB, Rizvi SI. Plant polyphenols as dietary antioxidants in human health and disease. Oxidative Med Cell Longev. 2009;2(5):270-8.

21. Apak R, Özyürek M, Güçlü K, Çapanoğlu E. Antioxidant activity/capacity measurement. 1. Classification, physicochemical principles, mechanisms, and electron transfer (ET)-based assays. J Agric Food Chem. 2016;64(5):997-1027.

22. Apak R, Özyürek M, Güçlü K, Çapanoğlu E. Antioxidant activity/capacity measurement. 2. Hydrogen atom transfer (HAT)-based, mixed-mode (electron transfer (ET)/HAT), and lipid peroxidation assays. J Agric Food Chem. 2016;64(5):1028-45.

23. Zheng Y, Li XK, Wang Y, Cai L. The role of zinc, copper and iron in the pathogenesis of diabetes and diabetic complications: therapeutic effects by chelators. Hemoglobin. 2008;32(1-2):135-45.

24. Boudjeko T, Megnekou R, Woguia AL, Kegne FM, Ngomoyogoli JE, Tchapoum CD, Koum O. Antioxidant and immunomodulatory properties of polysaccharides from Allanblackia floribunda Oliv stem bark and Chromolaena odorata (L.) king and H.E. Robins leaves. BMC Res Notes. 2015;8:759.

25. Flora SJ. Structural, chemical and biological aspects of antioxidants for strategies against metal and metalloid exposure. Oxidative Med Cell Longev. 2009;2(4):191-206.

26. Wojdyło A, Oszmiański J, Czemerys R. Antioxidant activity and phenolic compounds in 32 selected herbs. Food Chem. 2007;105(3):940-9.

27. Jiménez N, Carrillo-Hormaza L, Pujol A, Álzate F, Osorio E, Lara-Guzman O. Antioxidant capacity and phenolic content of commonly used antiinflammatory medicinal plants in Colombia. Ind Crop Prod. 2015;70:272-9.

28. Floegel A, Kim D-O, Chung S-J, Koo SI, Chun OK. Comparison of ABTS/DPPH assays to measure antioxidant capacity in popular antioxidant-rich US foods. J Food Comp Anal. 2011;24(7):1043-8.

29. Kedare SB, Singh RP. Genesis and development of DPPH method of antioxidant assay. J Food Sci Tech. 2011;48(4):412-22.

30. Apak R, Guclu K, Demirata B, Ozyurek M, Celik SE, Bektasoglu B, Berker K Ozyurt D. Comparative evaluation of various total antioxidant capacity assays applied to phenolic compounds with the CUPRAC assay. Molecules. 2007;12(7):1496-547

31. Sharma P, Jha AB, Dubey RS, Pessarakli M. Reactive oxygen species, oxidative damage, and antioxidative defense mechanism in plants under stressful conditions. J Bot. 2012;2012:26.

32. Luyen BT, Tai BH, Thao NP, Yang SY, Cuong NM, Kwon Yl, Jang HD, Kim YH. A new phenylpropanoid and an alkylglycoside from Piper retrofractum leaves with their antioxidant and alpha-glucosidase inhibitory activity. Bioorg Med Chem Lett. 2014;24(17):4120-4.

33. Palasuwan A, Soogarun S, Lertlum T, Pradniwat $P$, Wiwanitkit V. Inhibition of Heinz body induction in an in vitro model and total antioxidant activity of medicinal Thai plants. Asian Pac J Cancer Prev. 2005;6(4):458-63.

34. Kandikattu HK, Rachitha P, Krupashree K, Jayashree GV, Abhishek V, Khanum F. LC-ESI-MS/MS analysis of total oligomeric flavonoid fraction of Cyperus rotundus and its antioxidant, macromolecule damage protective and antihemolytic effects. Pathophysiology. 2015;22(4):165-73.

35. Panich U, Kongtaphan K, Onkoksoong T, Jaemsak K, Phadungrakwittaya R, Thaworn A, Akarasereenont P, Wongkajornsilp A. Modulation of antioxidant defense by Alpinia galanga and Curcuma aromatica extracts correlates with their inhibition of UVA-induced melanogenesis. Cell Biol Toxicol. 2010;26(2):103-16.

36. Hanish Singh JC, Alagarsamy V, Sathesh Kumar S, Narsimha RY. Neurotransmitter metabolic enzymes and antioxidant status on Alzheimer's disease induced mice treated with Alpinia galanga (L.) Willd. Phytother Res. 2011;25(7):1061-7.

37. Kim I, Kim HR, Kim JH, Om AS. Beneficial effects of Allium sativum L. stem extract on lipid metabolism and antioxidant status in obese mice fed a high-fat diet. J Sci Food Agr. 2013;93(11):2749-57.

38. Kazeem MI, Akanji MA, Yakubu MT, Ashafa AO. Protective effect of free and bound polyphenol extracts from ginger (Zingiber officinale roscoe) on the hepatic antioxidant and some carbohydrate metabolizing enzymes of streptozotocin-induced diabetic rats. Evid Based Complement Alternat Med. 2013;2013:935486

39. Khaliq F, Parveen A, Singh S, Gondal R, Hussain ME, Fahim M. Improvement in myocardial function by Terminalia arjuna in streptozotocin-induced diabetic rats: possible mechanisms. J Cardiovasc Pharmacol Ther. 2013;18(5):481-9.

40. Abu MN, Samat S, Kamarapani N, Nor Hussein F, Wan Ismail WI, Hassan HF. Tinospora crispa ameliorates insulin resistance induced by high fat diet in wistar rats. Evid Based Complement Alternat Med. 2015;2015:985042.

41. Baskaran UL, Martin SJ, Mahaboobkhan R, Prince SE. Protective role of Triphala, an Indian traditional herbal formulation, against the nephrotoxic effects of bromobenzene in Wistar albino rats. J Integr Med. 2015;13(2):115-21.

\section{Submit your next manuscript to BioMed Central and we will help you at every step:}

- We accept pre-submission inquiries

- Our selector tool helps you to find the most relevant journal

- We provide round the clock customer support

- Convenient online submission

- Thorough peer review

- Inclusion in PubMed and all major indexing services

- Maximum visibility for your research

Submit your manuscript at www.biomedcentral.com/submit
) Biomed Central 